\title{
PENGATURAN DAN IMPLEMENTASI MENGENAI HAK ANAK YANG BERKONFLIK DENGAN HUKUM DI INDONESIA (Studi di Pengadilan Negeri Surabaya dan Rumah Tahanan Medaeng)
}

\author{
Tresilia Dwitamara \\ Fakultas Hukum Universitas Airlangga Surabaya \\ e-mail: tresilia.dwitamara@gmail.com
}

\begin{abstract}
ABSTRAK
Secara psikologis, anak bukanlan miniatur orang dewasa, namun anak adalah suatu subyek yang masih dalam tahap perkembangan dengan kapasitas yang rawan, yang mana berkaitan dengan hubungan sebab akibat antara pemenuhan dan perlindungan akan hak hidup, hak bertahan hidup, hak tumbuh dan berkembang anak, yang mana juga termasuk hak untuk mendapatkan perlindungan dari kekerasan dan diskriminasi. Perlu ditekankan bahwa hak untuk hidup tidak bisa dilepaskan dengan hak atas kelangsungan hidup, dan hak untuk tumbuh dan berkembang. Terutama bagi anak-anak yang masih dalam masa pertumbuhan dan perkembangan, dimana setiap luka, kerusakan, atau mengurangi hak anak untuk kelangsungan hidup akan mengakibatkan suatu akibat yang serius dan fatal terhadap kondisi anak. Kecenderungan untuk membawa anak ke peradilan anak, mengakibatkan anak akan selalu menjadi target kriminalisasi. Jadi tidak boleh dibawa ke pengadilan jika tidak perlu. Hal ini tentu saja tidak hanya mempengaruhi anak secara fisik, tetapi juga psikologis. Sistem pemidanaan edukatif yang berlaku di Indonesia saat ini belum seperti yang diharapkan. Perlindungan anak yang dikualifikasikan sebagai seorang kriminal benar-benar harus mendapatkan perhatian serius dari pemerintah. Anak yang berkonflik dengan hukum dalam posisi anak sebagai seorang kriminal yang membutuhkan perlindungan dan keamanan membutuhkan perlindungan khusus yang menjamin kepentingan anak.
\end{abstract}

Kata Kunci: kriminalitas, penjara anak, perlindungan anak.

\begin{abstract}
Psychologically, child instead of a miniature adult but child is a subject that is still in the developmental stage capacity-prone (evolving capacities), which is closely related to the causality between the fulfillment and protection of the right to life and the right to survival, the right to grow and develop the child as well as the right to be protected from violence and discrimination. It should be emphasized that the right to life can not be released to the right to survival, and the right to grow and develop. Especially for children who are still in a period of growth and development, where each wound, destruction, or reducing the child's right to survival will resulting in serious and fatal child's condition. The tendency to bring the child to the juvenile justice machine, then the children will always be the target of criminalization. So it should not be taken to court if it does not need. This is of course not only affects the child physically, but also psychologically. Educative criminal system prevailing in Indonesia at this time has not been as expected. Protection of children whom qualified as criminals really have to get serious attention from the government. Children in conflict with the law in the position of children as criminals in need of protection and security in addition to self-regulation also requires a special protection that ensures the interests of the child.
\end{abstract}

Keywords: criminality, juvie, child protection.

\section{PENDAHULUAN}

Anak sebagai salahsatu sumber daya manusia dan merupakan suatu generasi penerus bangsa, sudah selayaknya mendapatkan perhatian yang khusus dari pemerintah, dalam rangka pembinaan anak untuk mewujudkan sumber daya manusia yang tangguh serta berkualitas. Berkaitan dengan hal pembinaan 
anak diperlukan sarana dan prasarana hukum yang mengantisipasi segala permasalahan yang timbul. Sarana dan prasarana yang dimaksud menyangkut kepentingan anak atau pun juga yang menyangkut penyimpangan sikap dan perilaku yang menjadikan anak terpaksa dihadapkan ke muka pengadilan.

Mental anak yang masih dalam tahap pencarian jati diri, kadang mudah terpengaruh dengan situasi dan kondisi lingkungan di sekitarnya. Sehingga jika lingkungan tempat anak berada tersebut buruk, dapat terpengaruh pada tindakan yang dapat melanggar hukum. Hal itu tentu saja dapat merugikan dirinya sendiri dan juga masyarakat. Tidak sedikit tindakan tersebut akhirnya menyeret mereka berurusan dengan aparat penegak hukum.

Anak merupakan bagian dari masyarakat, mereka mempunyai hak yang sama dengan masyarakat lain yang harus dilindungi dan dihormati. Setiap negara dimanapun di dunia ini wajib memberikan perhatian serta perlindungan yang cukup terhadap hak-hak anak, yang antara lain berupa hak-hak sipil, ekonomi, sosial dan budaya. Namun sepertinya kedudukan dan hakhak anak jika dilihat dari perspektif yuridis belum mendapatkan perhatian serius baik oleh pemerintah, penegak hukum maupun masyarakat pada umumnya dan juga masih jauh dari apa yang sebenarnya harus diberikan kepada mereka. Kondisi ini pun dipersulit oleh lemahnya penerapan hukum mengenai hak-hak anak yang dilakukan oleh aparat penegak hukum itu sendiri.

Hak asasi anak merupakan bagian dari hak asasi manusia yang mendapat jaminan dan perlindungan hukum internasional maupun hukum nasional, yang secara universal pun dilindungi dalam Universal Declaration of Human Right (UDHR), International on Civil and Political Rights (ICPR). Pembedaan perlakuan terhadap hak asasi anak dengan orang dewasa, diatur dalam konvensi-konvensi internasional khusus. Sebagaimana diutarakan dalam Deklarasi Hak-Hak Anak, the child, by reasons of his physical and mental immaturity, needs special safeguards and care, including appropriate legal protection, before as well as after birth..." Deklarasi Wina Tahun 1993 yang dihasilkan oleh Konferensi Dunia tentang HakHak Asasi Manusia (yang selanjutnya disebut HAM), kembali menekankan prinsip First Call for Children, yang menekankan pentingnya upaya-upaya nasional dan internasional untuk memajukan hak-hak anak atas survival protection, development and participation (Harkristuti Harkrisnowo, 2002:4).

Di Indonesia telah dibuat peraturan-peraturan yang pada dasarnya sangat menjunjung tinggi dan memperhatikan hak dari anak yaitu diratifikasinya Konvensi atas Hak Anak (yang selanjutnya disebut KHA) dengan Keputusan Presiden No. 36 Tahun 1990. Peraturan perundangan lain yang telah dibuat oleh pemerintah Indonesia antara lain, UU No. 39 Tahun 1999 tentang Hak Asasi Manusia, UndangUndang No. 3 Tahun 1997 tentang Pengadilan Anak yang diperbarui pada Undang-Undang No. 11 Tahun 2012 tentang Sistem Peradilan Pidana Anak, UndangUndang No. 23 Tahun 2002 tentang Perlindungan Anak. Secara substansinya undang-undang tersebut mengatur hak-hak anak yang berupa, hak hidup, hak atas nama, hak pendidikan, hak kesehatan dasar, hak untuk beribadah menurut agamanya, hak berekspresi, berpikir, bermain, berkreasi, beristirahat, bergaul dan hak jaminan sosial.

Dibuatnya aturan-aturan tersebut itu sangat jelas terlihat bahwa negara sangat memperhatikan dan melindungi hak-hak anak. Hak-hak anak tersebut wajib dijunjung tinggi oleh setiap orang. tetapi dalam pengaplikasiannya masalah penegakan hukum atau law enforcement sering mengalami hambatan maupun kendala baik yang disebabkan karena faktor internal maupun faktor eksternal.

Salah satunya adalah dalam sistem pemidanaan terhadap anak yang sampai sekarang terkadang masih memperlakukan anak-anak yang mana terlibat sebagai pelaku tindak pidana itu seperti pelaku tindak pidana yang dilakukan oleh orang dewasa. Anak ditempatkan dalam posisi sebagai seorang pelaku kejahatan yang patut untuk mendapatkan hukuman yang sama dengan orang dewasa dan berlaku di Indonesia.

Padahal pemidanaan itu sendiri lebih berorientasi kepada individu pelaku yang mana biasa disebut dengan pertanggungjawaban individual atau juga personal (Individual responsibility) dimana pelaku dipandang sebagai individu yang berkemampuan untuk bertanggungjawab penuh terhadap perbuatan yang telah dilakukannya. Sedangkan anak merupakan individu yang belum dapat menyadari secara penuh atas tindakan atau perbuatan yang dilakukannya, hal ini disebabkan karena anak merupakan individu yang belum matang dalam berpikir. Tanpa disadari hal tersebut tentu saja dapat menimbulkan dampak psikologis yang cukup hebat bagi anak yang pada akhirnya mempengaruhi perkembangan mental dan jiwa dari si anak tersebut. Oleh sebab itu dengan memperlakukan anak itu sama dengan orang dewasa maka dikhawatirkan si anak akan dengan cepat meniru perlakuan dari orang-orang yang ada di dekatnya.

Kenakalan anak atau juga dalam istilah asingnya disebut dengan Juvenile Deliquency, dibahas dalam 
Badan Peradilan Amerika Serikat dalam usaha untuk membentuk suatu Undang-Undang Peradilan Anak. Ada dua hal yang menjadi topik pembicaraan utama yaitu segi pelanggaran hukumnya dan sifat tindakan anak apakah sudah menyimpang dari norma yang berlaku dan melanggar hukum atau tidak. Juvenile Deliquency adalah suatu tindakan atau perbuatan pelanggaran atas norma, baik norma hukum maupun norma sosial yang dilakukan oleh anak-anak usia muda (Wagiati Soetodjo, 2006:11).

Ketentuan kejahatan anak atau disebut delikuensi anak itu diartikan sebagai bentuk kejahatan yang dilakukan anak dalam titel-titel khusus dari bagian KUHP dan atau tata peraturan perundang-undangan (Maulana Hassan Wadong, 2000:81).

Pengadilan anak dibentuk karena dilatarbelakangi oleh sikap keprihatinan yang melanda negara-negara Eropa dan juga Amerika atas tindakan kriminalisasi yang dilakukan anak dan pemuda yang jumlahnya dari tahun ke tahun itu semakin meningkat. Namun perlakuan terhadap pelaku tindak kriminal dewasa, sehingga diperlukan tindakan perlindungan khusus bagi pelaku kriminal anak-anak. Pengadilan anak dimaksudkan untuk menanggulangi keadaan yang kurang menguntungkan bagi anak-anak, dan dalam pelaksanaan proses peradilan pidana anak tidak boleh diperlakukan sama seperti orang dewasa.

Di Indonesia sendiri dalam rangka mewujudkan suatu peradilan yang benar-benar memperhatikan kepentingan anak perlu diwujudkan peradilan yang terbatas bagi anak untuk dapat menjamin kepentingan anak melalui Undang-Undang No. 3 Tahun 1997 tentang Pengadilan Anak, yang mana disahkan oleh Pemerintah pada 3 Januari Tahun 1997, sedangkan pada Undang-Undang No. 11 Tahun 2012 tentang Pengadilan Anak yang diperbarui serta disahkan oleh pemerintah pada tanggal 30 Juli 2012 tetapi mulai berlaku pada tanggal 30 Juli 2014. Peradilan khusus bagi anak diadakan guna mengatasi permasalahan tindak pidana yang dilakukan oleh mereka yang masih termasuk golongan anak-anak, semuanya wajib disidangkan dalam peradilan bagi anak yang ada pada pengadilan di lingkungan peradilan umum.

Undang-Undang tentang Pengadilan Anak akan memberikan landasan hukum yang bersifat nasional untuk kepentingan perlindungan hukum bagi anak melalui tatanan peradilan anak. Selain itu UndangUndang No. 3 Tahun 1997 tentang Pengadilan Anak, yang ditujukan sebagai perangkat hukum yang lebih mantap dan memadai dalam melaksanakan pembinaan dan memberikan perlindungan hukum terhadap anak yang bermasalah dengan hukum maupun penegakan hak-hak anak dan hukum anak untuk mewujudkan prinsip kepentingan yang mana terbaik bagi anak (the best interest of the child). Ketentuan yang ada dalam Undang-Undang No. 3 tahun 1997 mengenai Pengadilan Anak yang telah sebagian mengacu pada rambu-rambu semacam ini. Perampasan kemerdekaan misalnya, haruslah dilakukan hanya sebagai measure of the last resort, hal mana berkenaan dengan hak anak untuk tidak dipisahkan dari orangtuanya (Harkristuti Harkrisnowo, 2002:8).

Anak sebagai individu yang belum dewasa perlu mendapatkan perlindungan hukum atau yuridis (legal protection) agar terjamin kepentingannya sebagai anggota masyarakat. Masalah penegakan hak-hak anak dan penegakan hukum anak, pada dasarnya adalah sama dengan masalah pada penegakan hukum dalam aspek secara keseluruhan.

Untuk terciptanya suatu keseimbangan dalam masyarakat, maka diadakan sanksi. Sanksi tersebut dibentuk dari suatu sistem atau lembaga yang mana berwenang untuk menanganinya. Semua masyarakat mempunyai sistem kelembagaan dalam menangani kejahatan dan kenakalan, yang merupakan reaksi terhadap terjadinya kejahatan dan kenakalan sistem kelembagaan yang dimaksud itu adalah Kepolisian, Pengadilan, Custodial Institutions, dan juga berbagai metode supervise dan pembinaan petindak pidana dalam masyarakat (misalnya probation dan parole). Tujuan dari reaksi terhadap kejahatan dan kenakalan adalah untuk pencegahan terhadap kejahatan dan kenakalan, serta resosialisasi tindak pidana.

Sistem pemidanaan yang sedang berlaku saat ini di Indonesia hanya bertumpu pada sifat pemidanaannya saja tanpa memperhatikan pembinaan bagaimana dapat merubah si anak tersebut menjadi lebih baik. Diberikannya sistem pemidanaan yang mana bersifat edukatif, yaitu suatu sistem pemidanaan yang tidak hanya menekankan dari segi pemidanaannya saja namun lebih kepada bagaimana caranya agar seorang anak itu bisa dirubah perilakunya menjadi lebih baik dan tidak akan mengulangi tindakannya tersebut tanpa harus diberikan sanksi badan atau penjara.

Hal ini dapat dilihat dalam Undang-Undang No. 23 Tahun 2002 tentang Perlindungan Anak pada Pasal 17 ayat 1 , yaitu setiap anak yang dirampas kebebasannya berhak untuk: 1 . Mendapat perlakuan secara manusiawi dan penempatannya dipisahkan dari orang dewasa; 2. Memperoleh bantuan hukum atau bantuan lainnya secara efektif dalam setiap tahapan upaya hukum yang berlaku, misalnya bimbingan sosial dari pekerjaan sosial, konsultasi dari psikolog dan psikiater atau juga bantuan dari ahli bahasa; 3 . 
Membela diri dan memperoleh keadilan di depan pengadilan anak yang objektif dan tidak memihak dalam bidang tertutup untuk umum.

Seorang pelaku kejahatan yang dilakukan oleh anak-anak akan lebih mudah pengendaliannya dan perbaikannya daripada seorang pelaku kejahatan yang dilakukan oleh orang dewasa. Hal ini disebabkan karena taraf perkembangan anak itu sangat berlainan dengan sifat-sifatnya dan ciri-cirinya, pada usia bayi, remaja dewasa dan usia lanjut akan berlainan psikis maupun jasmaninya. Sistem pemidanaan dengan pemberian sanksi pidana yang mana sifatnya adalah edukatif atau mendidik selama ini jarang dilakukan oleh aparat penegak hukum di Indonesia khususnya oleh hakim. Salah satu contoh sanksi pidana yang bersifat edukatif adalah pemberian sanksi pidana yang tidak hanya dikembalikan kepada orangtua/ wali atau lingkungannya saja namun sanksi pidana tersebut sifatnya juga mendidik misalnya dimasukkan ke pondok pesantren bagi pelaku tindak pidana yang beragama Islam, atau diberikan kepada gereja bagi yang beragama nasrani, dan lembaga keagamaan lainnya yang sesuai dengan agama yang dipeluk atau dianutnya.

Sistem pemidanaan individual atau individual responsibility yang digunakan selama ini adalah upaya penanggulangan kejahatan yang bersifat fragmentair yaitu hanya melihat upaya pencegahan tersebut dari segi individu atau personalnya saja. Padahal dalam menangani masalah anak ini tidak hanya dilihat dari penanggulangan individu si anak saja melainkan dilihat dari sekian banyak faktor, salah satunya adalah membuat bagaimana si anak tidak lagi mengulangi perbuatannya namun juga memberikan teladan dan pendidikan yang baik kepada si anak.

Hal ini dimaksudkan agar mental spiritual si anak itu lebih terdidik sehingga perilaku yang menyimpang dari si anak ini pun akan menjadi lebih baik. Dengan dimasukkannya si anak sebagai pelaku kejahatan ke Pemasyarakatan bukannya tidak menjamin bahwa si anak tersebut akan dapat berubah, namun di dalam Pemasyarakatan tersebut tidak ada masukan yang lebih bagi perbaikan mental spiritual anak karena mereka sedang diasingkan bersama-sama dengan para pelaku tindak pidana lain hal ini mengakibatkan proses pemulihan perilaku si anak untuk menjadi lebih baik seringkali terhambat yang disebabkan lingkungan dari dalam Pemasyarakatan itu sendiri yang kurang kondusif.

Tentunya hal ini akan berbeda jika menempatkan si anak pada suatu lingkungan dimana dia tidak merasa diperlakukan sebagai seorang pelaku tindak pidana, namun lebih memperlakukan si anak sebagai seorang manusia yang belum dewasa yang masih belum tahu apa-apa sehingga masih perlu diberikan bimbingan, pengarahan serta pengajaran yang disebut dengan tindakan baik dan mana yang disebut dengan tindakan buruk. Tentu saja perlakuan yang diberikan kepada mereka yang terlibat tindak pidana, selama dalam proses hukum dan pemidanaannya menempatkan mereka sebagai pelaku tindak kriminal muda yang mempunyai perbedaan karakteristik dengan pelaku tindak kriminal dewasa.

\section{RUMUSAN MASALAH}

Berdasarkan pada uraian tersebut di atas masalah perlindungan terhadap anak-anak sangatlah luas, maka disini penulis membatasi masalah tersebut khususnya bagi anak sebagai pelaku tindak pidana, dengan motif dan berbagai saran yang digunakan. Sehingga masalah pokok tersebut dapatlah dirumuskan permasalahan sebagai berikut: Pertama, Bagaimana pengaturan konsepsi yuridis dan konsepsi non-yuridis hak anak yang berkonflik dengan hukum di Indonesia. Kedua, Bagaimana implementasi hak anak yang berkonflik dengan hukum di Pengadilan Negeri Surabaya dan Rumah Tahanan Medaeng.

\section{METODE PENELITIAN}

Penelitian ini merupakan suatu penelitian hukum normatif. Pentingnya penelitian hukum normatif ini karena dilandasi oleh karakter khas ilmu hukum yang mana terletak pada metode penelitiannya, yaitu penelitian yang bersifat normatif. Penelitian hukum ini normatif karena yang dikaji adalah norma-norma yang diterapkan di masyarakat terutama yang berlaku di Rumah Tahanan Medaeng.

\section{PEMBAHASAN \\ Analisis Yuridis terhadap Anak yang Berkonflik dengan Hukum}

Dalam rangka penegakan hukum kepada pelaku tindak pidana harus dikenakan suatu akibat hukum, hal yang erat kaitannya adalah masalah pemidanaan. Hal tersebut berkaitan dengan tujuan dari penegakan hukum yang hendak dicapai yaitu pemenuhan rasa keadilan dan pencapaian kepastian hukum. Dengan demikian pemahaman tentang tujuan dari pemidanaan hal ini penting untuk mengetahui maksud ditegakkan hukum itu.

Sifat pemidanaan ini bukanlah semata-mata hanya bersifat punitif (menghukum) maupun mencari-cari kesalahan anak tetapi untuk memperbaiki anak dengan menghindarkannya dari perbuatan-perbuatan yang 
asosial. Selain itu usaha-usaha pemidanaan anak harus non viktimasi (jangan menimbulkan korban terhadap anak tersebut) baik yang nonstruktural (fisik) maupun struktural (sosial). Pemidanaan terhadap anak bukan merupakan balasan atas perbuatannya. Kalaupun anak harus bertanggungjawab atas perbuatannya yang merugikan orang lain, maka haruslah ditekankan kepadanya bahwa bentuk hukuman bukanlah harga mati atau pembalasan atas perbuatannya. Dengan demikian maka akan lebih tercipta keadilan.

Dalam Undang-Undang Perlindungan Anak, tidak adanya pengaturan mengenai batasan akan pidana minimum dan pidana maksimum. Menurut sistem Undang-Undang Perlindungan Anak, penjatuhan sanksi yang tepat untuk kepentingan terbaik bagi anak dilaksanakan melalui upaya rehabilitasi. Anak yang berkonflik dengan hukum merupakan tanggungjawab pemerintah dan masyarakat.

Undang-Undang No. 23 Tahun 2002 di dalam Pasal 59 jo. Pasal 64 ayat 1 dan ayat 2. Dalam pasal tersebut di atas dijelaskan bahwa pemidanaan terhadap anak bukanlah semata-mata penghukuman tetapi rehabilitasi dalam rangka pendidikan dan pencegahan. Dengan demikian diberikannya hukuman kepada anak bukanlah sebagai pemberi rasa sakit namun sebagai pembinaan sehingga dengan pembinaan itu sebagai pemberi rasa sakit namun sebagai pembinaan sehingga dengan pembinaan diharapkan anak dapat menyadari perbuatannya dan dapat kembali ke tengah-tengah masyarakat untuk melanjutkan masa depannya.

Kesadaran nasional atau justifikasi konstitusional melindungi anak sebagai suatu urusan utama dalam berbangsa dan bernegara, tertuang dalam Pasal 28 ayat 2 UUD 1945 secara ekplisit telah menegaskan hak-hak konstitusional anak yang berbunyi: Setiap anak itu berhak atas kelangsungan hidup, tumbuh dan berkembang, dan perlindungan dari berbagai bentuk kekerasan dan diskriminasi. Oleh karena itu, Negara Republik Indonesia secara konstitusional telah eksplisit mengakui, menghormati dan melindungi hakhak konstitusional anak yakni: hak atas kelangsungan hidup; hak atas tumbuh dan berkembang, dan; hak atas perlindungan dari kekerasan dan diskriminasi;

Pengakuan, penghormatan dan juga jaminan serta perlindungan hak-hak anak dimaksud merupakan realisasi daripada kewajiban negara dan sekaligus pemenuhan hak-hak kewarganegaraan sebagai suatu penganugerahan hak-hak sosial kepada rakyatnya (the granting of social rights).

Berdasarkan Konvensi PBB tentang Hak Anak, secara konseptual tidak memisahkan antara hak hidup dengan hak kelangsungan hidup anak dan hak tumbuh dan berkembang anak yang dirumuskan dalam satu pasal dan ayat yang bersamaan. Bahkan, pengakuan atas hak hidup anak tersebut akan dipertegas dengan pengakuan hak atas kelangsungan hidup (rights to survival) dan hak atas tumbuh kembang (rights to development).

Lebih dari itu, terhadap integrasi antara hak hidup anak, hak kelangsungan hidup anak dan hak tumbuh dan kembang anak tersebut, negara menjamin (shall ensure) dengan segala upaya maksimal yang mungkin dilakukan negara (the maximum extent possible the survival and development), sebagaimana diatur dalam ketentuan Artikel 6 ayat 1 dan ayat 2 Convention on the Right of the Child (CRS) yang berbunyi sebagai berikut, State Parties recognize that every child has the inherent right to life; State Parties shall ensure to the maximum extent possible the survival and development.

Berdasarkan ketentuan di atas maka hak hidup anak, hak kelangsungan hidup anak dan hak tumbuh dan kembang anak merupakan hak asasi anak sebagai warga dunia dan hak konstitusional anak sebagai warga negara Indonesia yang dijamin Pasal 28B ayat 2 UUD 1945.

Pemenuhan akan hak konstitusional anak itu pada Pasal 28B ayat 2 masih terganggu dan terlanggar dengan kriminalisasi anak dalam usia terlalu dini, ataupun untuk menempatkan anak negara (yang bukan anak pidana) dengan perlakuan yang sama seperti anak pidana di dalam lembaga pemasyarakatan anak, ataupun bahkan rumah tahanan. Keadaan ini menjadi relevan dan memiliki kausalitas bahwa kriminalisasi anak mengakibatkan pelanggaran hak konstitusional anak dalam Pasal 28B ayat 2 UUD 1945. Padahal disadari betul adanya kerugian dan dampak buruk penahanan anak bersama orang dewasa, sebagaimana ditegaskan dalam KHA artikel 37c.

Secara normatif, bahwa adanya pemidanaan anak merupakan perbuatan melanggar hak konstitusional atas perlindungan dan kepastian hukum yang adil serta perlakuan sama di hadapan hukum. Padahal berdasarkan pada Pasal 28D di dalam ayat 1 UUD 1945 yang menegaskan bahwa, setiap orang berhak atas pengakuan, jaminan, perlindungan dan kepastian hukum yang adil serta perlakuan sama di hadapan hukum. Atas dasar itu, maka para hakim didorong untuk menggali rasa keadilan substantif (substantive justice) di masyarakat daripada terbelenggu ketentuan undang-undang (procedural justice).

Ketentuan Undang-Undang No. 3 Tahun 1997 tentang Pengadilan Anak pada ketentuan Pasal 1 Butir 2 Undang-Undang Pengadilan Anak. Bunyi 
Pasal 1 butir 2 di atas dapat juga dikatakan bahwa ketentuan Pasal 1 butir 2 huruf b Undang-Undang Pengadilan Anak yang mana berbunyi, anak yang melakukan perbuatan yang dinyatakan terlarang bagi anak, baik menurut peraturan perundang-undangan maupun menurut peraturan hukum lain yang hidup dan berlaku dalam masyarakat yang bersangkutan, menjadi hukum positif yang mengakibatkan anak dikualifikasi sebagai anak nakal apabila melakukan perbuatan yang dikualifikasi sebagai: 1 . Perbuatan tertentu, yang dinyatakan terlarang bagi anak, baik menurut peraturan perundang-undangan; 2 . Perbuatan yang menurut peraturan hukum lain yang hidup dan berlaku dalam masyarakat yang bersangkutan.

Ketentuan tersebut menjadi dasar kriminalisasi anak, selain melakukan perbuatan terlarang karena perbuatan tersebut dilarang 'menurut peraturan hukum lain yang hidup dan berlaku dalam masyarakat yang bersangkutan'. Jadi tidak hanya atas perbuatan yang merupakan tindak pidana (Pasal 1 butir 2 huruf a Undang-Undang Pengadilan Anak), dan perbuatan yang mana terlarang menurut peraturan perundangundangan (Pasal 1 butir 2 huruf a Undang-Undang Pengadilan Anak).

Ketentuan di atas merupakan alasan mengapa anak nakal itu diajukan ke proses peradilan pidana, karena anak nakal termasuk dalam hal ini perbuatan yang 'menurut peraturan hukum lain yang hidup dan berlaku dalam masyarakat yang bersangkutan', dapat dibawa ke proses peradilan pidana, padahal anak tersebut tidak dikualifikasi melakukan perbuatan pidana. Disinilah kausalitas dan dasar kriminalisasi anak yang melakukan perbuatan bukan perbuatan pidana.

Sesuai dengan teori hukum, dalam hal mengenakan hukuman pidana kepada seseorang (subjek hukum) hanya dapat dijatuhkan kepada orang apabila sudah ditetapkan lebih dulu dalam undang-undang, yang dalam hukum pidana dikenal dengan asas legalitas. Asas legalitas ini (sesuai doktrin, salah satunya hak untuk tidak dituntut atas dasar hukum yang berlaku surut) dijamin dalam Pasal 28I UUD 1945. Bahwa asas legalitas dianut dalam Pasal 1 ayat 1 KUHP, sehingga seorang tidak dapat dihukum apabila tidak ditetapkan terlarang menurut undang-undang. Oleh karena itu tidak dapat dijatuhi pidana apabila bukan merupakan suatu tindak pidana (strafbaar feit) yang diatur secara tertulis dan juga disahkan lebih dahulu sebelum adanya perbuatan yang dilarang. Relevan dengan itu, pakar hukum pidana Hamel (1927) dan Noyon-Langemeyer, menyatakan bahwa strafbaar feit sebagai kelakuan orang yang dirumuskan dalam undang-undang, yang bersifat melawan hukum, yang mana patut dipidanakan dengan kesalahan (Martiman Prodjohamidjojo, 1996:15).

Asas legalitas adalah asas universal dalam hukum pidana yang menjadi dasar hukum dibenarkannya penjatuhan hukuman pidana atau kriminalisasi pada orang termasuk anak. Asas legalitas adalah bagian dari sistem hukum yang dibangun dari sejumlah asas-asas hukum (legal principles) yang melahirkan sejumlah norma hukum (legal norms), dan norma hukumlah yang melahirkan aturan-aturan hukum (legal rules), baik yang tertulis (peraturan) maupun tidak tertulis. Namun, dalam perkara pidana, yang dijadikan dasar menuntut seorang dan menjatuhkan pidana seseorang hanyalah peraturan hukum (aturan hukum yang tertulis). Hal ini dinamakan sebagai asas legalitas. Asas legalitas merupakan salah satu asas hukum pidana yang sifatnya universal, yang artinya digunakan di seluruh sistem hukum di dunia modern. Di Indonesia, asas legalitas secara tegas ditentukan dalam Pasal 1 ayat 1 KUHP yaitu suatu perbuatan tidak dapat dipidana, kecuali berdasarkan kekuatan ketentuan-ketentuan perundang-undangan pidana yang telah ada.

Dari pasal tersebut, yurisprudensi dan doktrin (keduanya merupakan sumber hukum) menegaskan bahwa unsur dari asas legalitas itu ada empat, yaitu: Pertama, Lex scripta, yang artinya harus dituangkan secara tertulis dalam suatu perundang-undangan. Contohnya, perbuatan mencuri dapat dipidana, karena tegas ancaman pidananya tertuang dalam Pasal 362 KUHP. Kedua, Lex certa, artinya perbuatan pidana yang dimaksud harus diuraikan unsur-unsurnya oleh undang-undang secara jelas dan lengkap. Ketiga, Non retroaktif, artinya seseorang hanya boleh dipidana, jika perbuatan yang dilakukannya itu memang sebelumnya telah diancamkan pidana dalam perundang-undangan, sebelum perbuatan tersebut dilakukan. Keempat, Dilarang menggunakan konstruksi, termasuk analogi (memperluas atau mempersempit berlakunya suatu peraturan).

Pencantuman asas legalitas dan non-retroaktif, untuk menjamin kepastian hukum bagi warga negara, diatur dalam Pasal 28I ayat 1 UUD 1945 yang tidak memberikan peluang untuk melakukan penyimpangan asas legalitas termasuk dalam prinsip non-retroaktif sebagai salah satu unsurnya. Hak konstitusional ini sudah jelas ditegaskan dalam Pasal 28I ayat 1 UUD 1945 yang menyatakan hak untuk diakui sebagai pribadi di hadapan hukum, dan juga hak untuk tidak dituntut atas dasar hukum yang berlaku surut adalah hak asasi manusia yang tidak dapat dikurangi dalam 
keadaan apapun. Ketentuan Pasal 1 butir 2 huruf b UU No. 3 Tahun 1997 tentang Pengadilan Anak dimana kalimat menurut peraturan hukum lain yang hidup dan berlaku dalam masyarakat yang bersangkutan, telah menyimpang ataupun melampaui asas legalitas dalam hukum pidana (Pasal ayat 1 KUHP) yang dikenal dengan asas Nullum delictum nulla poenasine previa lege poenali dan karenanya bertentangan dengan Pasal 28I ayat 1 , Pasal 28B ayat 2, Pasal 28D ayat 1 UUD 1945.

Maka beralasan bilamana asas legalitas ini tetap dipertahankan dalam KUHP dan sampai saat ini tetap diterapkan baik dalam teori hukum pidana maupun dalam hukum pidana positif, dengan demikian jelaslah ketentuan Pasal 1 butir 2 huruf $b$ telah bertentangan dengan asas legalitas dalam hukum pidana positif yang berarti menormakan kriminalisasi anak, karena membuat norma yang mengakibatkan anak-anak dapat diajukan ke sidang anak yang mana selanjutnya dapat dijatuhi pidana. Oleh karena, bunyi pada Pasal 1 butir 2 huruf b Undang-Undang No. 3 Tahun 1997 tentang Peradilan Anak bertentangan dengan asas legalitas dalam hukum pidana yang mengandung unsur Lex scripta, Lex certa, non-retroaktif, dan juga dilarang menggunakan konstruksi, termasuk analogi

Hukum pidana dan perumusan perbuatan pidana hanya bersumber pada undang-undang yang disahkan lebih dahulu, yang disebut dengan asas legalitas. Artinya pemidanaan haruslah berdasarkan undangundang (lege), yaitu bukan saja tertulis dalam bentuk undang-undang, akan tetapi juga produk perundangundangan lainnya. Hal ini berarti nanti akan terdapat kepastian hukum bagi setiap pencari keadilan (E.Y. Kanter dan S.R. Sianturi, 2002:74).

Maka dari itu Undang-Undang No. 3 Tahun 1997 tentang Peradilan Anak pada Pasal 1 butir 2 huruf $b$ bertentangan dengan Pasal 28B ayat 2, Pasal 28D, dan Pasal 28I ayat 1 UUD 1945, karena bertentangan dengan hak konstitusional anak yakni hak tumbuh dan berkembang oleh karena mengakibatkan anak dapat dijatuhi hukuman pidana penjara, sehingga terganggunya perkembangan anak, tercerabutnya hak pendidikan, hak berkumpul dengan keluarga dan hak tumbuh kembang anak lainnya.

Selain itu juga akan bertentangan dengan hak konstitusional anak, atas perlindungan anak dari suatu kekerasan oleh karena secara faktual maupun rasional anak-anak yang dijatuhi pidana dalam penjara atau anak dalam yang ditahan dalam banyak kasus dan keadaan, terbukti mengalami kekerasan baik fisik maupun psikis. Dan bertentangan dengan hak konstitusional anak, atas perlindungan anak dari diskriminasi, karena secara faktual maupun rasional, anak-anak yang dikriminalisasi itu, dan selanjutnya akan dijatuhi pidana dalam penjara atau anak berarti mengalami diskriminasi hukum, padahal semestinya anak tidak dijatuhkan pidana karena melakukan perbuatan yang menurut peraturan hukum lain hidup dan berlaku dalam masyarakat yang bersangkutan.

Selain melanggar hak konstitusional di dalam Pasal 28B ayat 2 UUD 1945, juga melanggar hak konstitusional warga negara termasuk anak, yakni hak atas kepastian hukum yang adil sebagaimana dijamin dalam Pasal 28D ayat 1 UUD 1945 yaitu bertentangan dengan hak konstitusional warga negara termasuk anak yakni hak atas tidak dijatuhi pidana atas perbuatan yang tidak merupakan tindak pidana, dan perbuatan melanggar peraturan perundang-undangan, sesuai asas legalitas. Hak asasi anak sebagai HAM, secara eksplisit sebagai suatu hak konstitusional, yang dalam pandangan konstitusi bukan saja wujud harmonisasi dan akomodasi pandangan dan instrumen HAM sebagai isu global, namun pengakuan HAM dalam konstitusi merupakan syarat negara hukum.

Ketentuan Undang-Undang No. 3 Tahun 1997 tentang Peradilan Anak pada Pasal 1 butir 2 huruf $\mathrm{b}$ telah mengacaukan antara tindak pidana dengan kenakalan anak, serta gagal dalam membedakan atau memberikan batasan yang konsisten mana tindak pidana (straafbaar) yang dilarang dalam undangundang (karena dapat diancamkan pidana), dengan yang mana merupakan kenakalan anak-anak (juvenile delinquency).

Ketentuan adat dan juga kebiasaan yang berlaku pada masyarakat bisa jadi malah merugikan anak, mengingat kultur masyarakat yang menempatkan anak di bawah kendali orangtua mengakibatkan pemidanaan anak. Dengan adanya pasal tersebut telah nyata berakibat pada pemenjaraan anak dan berpotensi digunakan oleh masyarakat dan kepolisian untuk mengadili anak yang dianggap bersalah karena melanggar adat-istiadat setempat.

\section{Analisis Non Yuridis Anak Berkonflik dengan Hukum}

Secara psikologis, anak bukan orang dewasa dalam ukuran mini melainkan anak merupakan subjek yang masih rawan dalam tahap perkembangan kapasitas (evolving capacities), yang sangat erat kaitannya dengan kausalitas antara pemenuhan dan perlindungan atas hak hidup dan hak kelangsungan hidupnya, hak atas tumbuh dan berkembang anak serta hak atas perlindungan dari suatu kekerasan dan juga dari diskriminasi. 
Sehingga dalam pemahaman juridis konstitusional, hak-hak anak tersebut tidak terpisah-pisahkan antara satu dengan yang lainnya, yakni antara hak hidup dan hak kelangsungan hidupnya, hak atas tumbuh dan berkembang anak serta hak atas perlindungan dari kekerasan dan diskriminasi.

Dalam keadaan yang konkret, misalnya gangguan tumbuh dan juga berkembang anak yang terpenjara akibat suatu putusan pidana, maka terjadilah kerugian konstitusional anak untuk kelangsungan hidup dan hak tumbuh dan berkembang anak, walaupun sah menurut hukum formil.

Perlulah kiranya ditegaskan bahwa hak hidup (rights to life) tidak dapat dilepaskan dengan hak kelangsungan hidup (right to survival), dan juga hak tumbuh dan berkembang (rights to development). Apalagi terhadap anak yang mana masih di dalam masa pertumbuhan dan perkembangan, dimana setiap pencideraan, perusakan, atau pengurangan atas hak kelangsungan hidup anak akan berakibat serius dan fatal bagi hak hidup anak.

Kecenderungan ini akan membawa anak ke mesin peradilan pidana anak, maka anak-anak akan selalu menjadi target kriminalisasi. Padahal penahanan, pemidanaan, merupakan upaya terakhir (ultimum remidium). Sehingga tidak sepatutnya dibawa ke pengadilan apabila tidak perlu. Hal ini tentu saja bukan hanya berpengaruh pada anak secara fisik, tetapi juga secara psikis.

Hukum perlindungan anak merupakan subsistem hukum dan tujuan hukum pidana, yang didalamnya meliputi pemahaman dasar terhadap asas-asas hukum pidana seperti asas territorial, asas personal aktif, asas personal pasif, asas universalitas, asas fictie, dan lain-lain. Ada dua langkah legislatif yang ditempuh untuk melindungi anak-anak yang terlibat dalam tindak pidana, yaitu Undang-Undang No. 3 Tahun 1997 tentang Pengadilan Anak dan Undang-Undang No. 12 Tahun 1995 tentang Pemasyarakatan. Adanya perumusan ketentuan Undang-Undang No. 3 Tahun 1997 tentang Peradilan Anak di Indonesia, menjadi suatu acuan yang mana lebih mengkhususkan kepada ketentuan hukum acara pidana anak. Adanya asas Lex spesialis derogat lex generalis menjadi ketentuan yang mengikat dari asas umum.

Ketentuan Undang-Undang No. 3 Tahun 1997 ini memperkenalkan istilah khusus bagi anak-anak yang umurnya sudah mencapai 12 tahun yang melakukan tindak pidana, apabila anak tersebut yang (terbukti) telah melakukan tindak pidana atau yang melakukan perbuatan yang terlarang bagi anak, tidak disebut sebagai 'penjahat' melainkan 'anak nakal' (Pasal 1 ayat 2). Undang-Undang No. 3 Tahun 1997 disebut sebagai hukum pidana anak yang khusus mengatur tentang peradilan anak yang didalamnya termasuk juga fenomena yuridis serta keutamaan legalitas dalam menangani delikuensi anak atau anak sebagai korban (victima) dari kejahatan pidana.

Ketentuan dalam Undang-Undang No. 3 Tahun 1997 tentang Peradilan Anak menjadi bagian dari pokok-pokok Hukum Pidana Anak positif. Dengan berlakunya ketentuan dalam Undang-Undang No. 3 Tahun 1997 sebagai hukum positif di Indonesia menghapuskan beberapa ketentuan pokok terhadap anak yang diatur dalam Pasal 45, 46 dan 47 Kitab Undang-Undang Hukum Pidana.

Sistem peradilan pidana anak (Juvenile Justice System) adalah segala sesuatu unsur sistem peradilan pidana yang terkait di dalam penanganan kasuskasus kenakalan anak, yang dapat mengakibatkan anak-anak berhadapan dengan hukum. Anak yang berhadapan dengan hukum adalah setiap anak yang telah dinyatakan bersalah melanggar hukum pidana yang berlaku; dan setiap anak yang menjadi korban dan/atau saksi dalam peristiwa kejahatan.

Kerterpaduan sistem peradilan pidana dimaknai sebagai "...the collective institution through which in accused offender passes until the accussation have been disposed of or the assessed punishment concluded ...." (Mappi FHUI, Lembaga Pengawasan Sistem Peradilan Pidana Terpadu, 2003, www.peman tauperadilan.com). Sistem peradilan pidana terpadu bukanlah suatu sistem yang mana bekerja dalam satu unit kerja atau bagian yang menyatu secara harfiah melainkan adanya suatu kombinasi yang serasi antar sub sistem untuk mencapai satu tujuan. Tujuan sistem peradilan anak terpadu seharusnya lebih ditekankan kepada upaya meresosialisasi, rehabilitasi dan juga kesejahteraan sosial karena dalam menangani kasus anak pemenuhan dan perlindungan hak-hak anak menjadi tujuan utama dan harus dilandasi dengan prinsip akan kepentingan yang terbaik bagi anak (the principle of the best interests of the child) dan tidak terabaikannya kesejahteraan anak. Kesejahteraan anak itu penting, antara lain karena: 1. Anak adalah potensi serta generasi penerus bangsa yang mana landasannya telah diletakkan oleh generasi sebelumnya; 2. Agar setiap anak mampu untuk memikul tanggungjawab tersebut, maka ia perlu mendapat kesempatan untuk tumbuh, berkembang secara wajar; 3. Bahwa di dalam masyarakat terdapat anak-anak yang kini mengalami hambatan kesejahteraan rohani, jasmani, sosial, dan ekonomi; 4. Anak belum mampu memelihara dirinya; 5. Bahwa menghilangkan hambatan tersebut hanya 
akan dapat dilaksanakan dan diperoleh apabila usaha kesejahteraan anak terjamin.

Bila ditinjau dari pihak yang mana berkewajiban penuh melaksanakan Konvensi Hak Anak dalam hal ini negara dan para pihak yang bertanggungjawab untuk memenuhi hak anak yaitu orang dewasa pada umumnya, Konvensi Hak Anak mengandung 3 (tiga) perintah yaitu: Penuhi ( fulfill) yaitu negara maupun orang dewasa harus memenuhi semua kebutuhan si anak; Lindungi (protect) yaitu negara maupun orang dewasa harus melindungi si anak dari bentuk apapun; Hormati (respect) yaitu negara maupun orang dewasa harus menghormati pendapat dari si anak.

Namun sistem pemidanaan di Indonesia pada saat ini, bagi anak yang sebagai pelaku tindak pidana pelaksanaannya lebih kepada memasukkan mereka ke dalam Lembaga Pemasyarakatan Anak daripada mengembalikan mereka kepada orangtua atau wali, ataupun kepada lembaga-lembaga sosial yang lainnya yang bergerak di bidang pendidikan, juga pembinaan dan latihan kerja. Praktek penanganan anak pelaku dilinkuen berlandaskan pada Undang-Undang No. 3 Tahun 1997 ternyata cenderung bersifat punitif.

Rumah Tahanan Negara sebagai suatu tempat penahanan sebelum putusan pengadilan ditetapkan, seringkali menempatkan anak bercampur bersama para tahanan dewasa. Pasal 45 ayat 3 dan ayat 4 Undang-Undang No. 3 Tahun 1997 menyebutkan bahwa tempat penahanan anak, harus dipisah dari tempat penahanan orang dewasa dan selama anak ditahan, kebutuhan jasmani, rohani, dan sosial anak harus tetap dipenuhi. Jumlah rumah tahanan khusus anak di Indonesia masih belum memenuhi. Biasanya pada prakteknya strategi yang dapat ditempuh untuk melindungi anak-anak yang terpaksa ditempatkan di rumah tahanan dewasa ialah dengan menempatkan mereka di dalam ruangan tersendiri dan terpisah dari tahanan dewasa. Hal ini ditujukan untuk menghindari akibat negatif karena dikhawatirkan dapat menularkan pengalaman-pengalaman jelek kepada anak sehingga dapat juga mempengaruhi perkembangan mentalnya. Namun karena keterbatasan yang ada sering terjadi kekurangan ruangan yang diperuntukkan bagi anak, yang akhirnya mengakibatkan anak-anak terpaksa ditempatkan dalam suatu Lembaga Pemasyarakatan yang diperuntukkan bagi orang dewasa, tetapi tetap dilakukan pemisahan berdasarkan jenis kelamin.

Penggabungan tahanan anak dengan para tahanan dewasa sangat berbahaya. Selain itu hal tersebut tidak mencerminkan perlindungan terhadap anak. Anak bisa saja mengetahui pengalaman-pengalaman melakukan kejahatan yang belum pernah mereka ketahui sebelumnya dan bahkan anak dapat menjadi korban pelecehan seksual selama mereka berada dalam tahanan tersebut.

\section{PENUTUP \\ Kesimpulan}

Dari penjabaran di atas, baik yang secara yuridis ataupun nonyuridis dapat ditarik kesimpulan:

Pertama, Ketentuan Undang-Undang No. 3 Tahun 1997 tentang Pengadilan Anak, Pasal 1 ayat 2 butir b, bertentangan dengan Pasal 28B ayat 2, Pasal 28D ayat 1, dan Pasal 28I ayat 1 UUD 1945. Hal ini memang telah dihapus atau dihilangkan pada Undang-Undang No. 11 Tahun 2012 tentang Sistem Peradilan Pidana Anak, akan tetapi tetap tidak dapat bisa menjelaskan perbedaan anak yang melakukan tindak pidana dan anak yang melakukan perbuatan kenakalan anak.

Kedua, Sistem pemidanaan edukatif yang mana berlaku di Indonesia pada saat ini belumlah sesuai yang diharapkan. Perlindungan anak sebagai pelaku tindak pidana benar-benar harus mendapat perhatian serius dari pemerintah. Anak yang berkonflik dengan hukum dalam posisi anak ini sebagai pelaku tindak pidana, maka selain membutuhkan perlindungan dan keamanan diri juga memerlukan proteksi berupa regulasi khusus yang menjamin kepentingan anak. Undang-Undang No. 3 Tahun 1997 pada dasarnya memberikan stigma terhadap anak. Pen-'cap'-an atau pelabelan terhadap anak bahwasanya ia sebagai pelaku tindak pidana memberikan efek yang besar bagi pertumbuhan psikologis anak. Pemberian stigma ini dimulai sejak si anak bersentuhan dengan proses hukum yang pertamakali di kepolisian hingga akhir di proses perkaranya.

Ketiga, Selain itu, ketentuan yang mana tercantum dalam Undang-Undang No. 3 Tahun 1997 tentang Pengadilan Anak itu lebih menekankan pada segi straf atau penghukuman, walaupun dijelaskan juga bahwa anak dapat dikembalikan kepada orangtua, wali atau juga orangtua asuh, dan juga Departemen Sosial. Namun dalam pelaksanaannya di lapangan para aparat penegak hukum lebih mengedepankan penjatuhan pidana penjara daripada sanksi yang mana dapat memperbaiki moral dari anak. Pengetahuan aparat penegak hukum khususnya di negara Indonesia tentang penanganan kasus anak yang memang masih kurang. Aturan yang diterapkan juga hampir sama perlakuannya dengan penerapan aturan bagi terpidana dewasa. Pertimbangan psikologis dan kepentingan si anak menjadi nomor dua. Padahal untuk penangan kasus anak itu seharusnya sangat berbeda dengan perlakuan pelaku tindak pidana oleh orang dewasa. 
Aturan-aturan yang telah mendasari terbentuknya perlindungan bagi anak semestinya wajib dikuasai dan dipahami dengan baik, sehingga dalam penerapan sanksi bagi anak lebih mengedepankan sanksi yang dapat bersifat lebih edukatif.

Keempat, Jumlah lembaga pemasyarakatan anak di Indonesia juga masih sangatlah terbatas menjadi salahsatu kendala bagi pemisahaan antara pelaku tindak pidana dewasa dan anak-anak sebagai pelaku tindak pidana. Maka tidaklah mengherankan kalau sebagian di wilayah Indonesia yang mana termasuk daerah terpencil, anak sebagai pelaku tindak pidana sering ditempatkan dalam rumah tahanan pelaku tindak pidana dewasa. Aturan yang akan berlaku pun bukan aturan yang dikhususkan bagi anak melainkan bagi dewasa, sehingga anak tidak menjadi lebih baik perbuatannya namun sebagian besar malah membuat anak semakin pintar dalam berbuat kejahatan karena mereka mendapat ilmu baru tentang kejahatan dari para pelaku tindak pidana dewasa.

\section{Rekomendasi}

Adapun saran yang ingin diberikan oleh penulis dari penjabaran kesimpulan di atas sebagai berikut:

Pertama, Diharapkan kepada para aparat penegak hukum agar memperhatikan ketentuan aturan yang diberlakukan kepada terdakwa yang dalam hal ini dikategorikan sebagai anak, sehingga ancaman pidana penjara menjadi alternatif terakhir dalam memberikan sanksi bagi anak.

Kedua, Demi kepentingan akan masa depan anak sebaiknya hakim dalam memutus perkara memberikan keringanan hukum dalam memberikan sanksi terhadap anak yang melakukan tindak pidana.

Ketiga, Sebaiknya kepada aparat penegak hukum dan masyarakat itu untuk memberikan penyuluhanpenyuluhan hukum yang secara aktif dan menyeluruh, khususnya kepada anak-anak mengenai dampak dari tindakan kriminal yang merugikan masyarakat itu sendiri.

Keempat, Membangun sekolah khusus bagi anakanak yang terlibat tindak pidana, menambah jumlah pesantren atau sekolah keagamaan dan Balai Latihan Kerja di tiap Kabupaten atau Kota di Indonesia.

Kelima, Menambah banyaknya jumlah Lembaga Pemasyarakatan Anak dan Rumah Tahanan Anak sesuai jumlah Kabupaten atau Kota di Indonesia.

Keenam, Menambah pengetahuan para aparat penegak hukum dalam penanganan kasus anak dan mempersiapkan aparat penegak hukum yang benarbenar khusus dibentuk untuk menangani suatu kasus kenakalan atau perbuatan pidana anak.

\section{DAFTAR PUSTAKA}

\section{Buku:}

Arief, Barda Nawawi, 2005, Beberapa Aspek Kebijakan Penegakan dan Pengembangan Hukum Pidana, Bandung: Citra Aditya Bakti. 2005, Perkembangan Sistem Pemidanaan di Indonesia, Bahan Penataran Nasional Hukum Pidana dan Kriminologi XI.

Chazawi, Adami, 2002, Pelajaran Hukum Pidana, Jakarta: Raja Grafindo Persada.

Harkrisnowo, Harkristuti, 2002, Tantangan dan Agenda Hak-Hak Anak, Newsletter Komisi Hukum Nasional, Edisi Februari 2002, Jakarta.

Joni, Mohammad dan Zulchaini Z. Tanamas, 2009, Aspek Hukum Perlindungan Anak, Bandung: Citra Aditya Bakti.

Kartono, Kartini, 1998, Patologi Sosial 2 - Kenakalan Remaja, Jakarta: Raja Grafindo Persada.

Mappi FHUI, 2003, Lembaga Pengawasan Sistem Peradilan Pidana Terpadu, www.pemantaupera dilan.com

Marlina, 2009, Peradilan Pidana Anak di Indonesia Pengembangan Konsep Diversi dan Restorative Justice, Bandung: Refki Aditama.

Musa, M., 2008, Peradilan Restoratif Suatu Pemikiran Alternatif Sistem Peradilan Anak di Indonesia, www.peradilanrestorative.com, 14 Februari 2008.

Nelwitis, Elwi Danil, 2002, Hukum Penitensier, Padang: Bagian Hukum Pidana Fakultas Hukum Universitas Andalas Padang.

Prodjohamidjojo, Martiman, 1996, Memahami Dasar-Dasar Hukum Pidana Indonesia 2, Jakarta: Pradnya Paramita.

Qirom, Syamsudin Meliala dan E. Sumaryono, 1985, Kejahatan Anak Suatu Tinjauan dari Psikologi dan Hukum, Cetakan I, Yogyakarta: Liberty.

Sianturi, S.R., 1996 Asas-Asas Hukum Pidana di Indonesia dan Penerapannya, Jakarta: Alumni.

Soekanto, Soerjono, 2006, Pengantar Penelitian Hukum, Jakarta: UI-Press.

Soemitro, Irma Setyowati, 1990, Aspek Hukum Perlindungan Anak, Jakarta: Bumi Aksara.

Soetodjo, Wagiati, 2006, Hukum Pidana Anak, Bandung: Refika Aditama.

Sunggono, Bambang, 2007, Metodologi Penelitian Hukum, Jakarta: Raja Grafindo Persada.

Unicef, 2004, Perlindungan terhadap Anak yang Berhadapan dengan Hukum, Jakarta: Unicef.

Wadong, Maulana Hassan, 2000, Pengantar Advokasi dan Hukum Perlindungan Anak, Jakarta: Grasindo. 
Willis, Sofyan S., 1981, Problema Remaja dan Pemecahannya, Bandung: Angkasa.

Wologito, Bimo, 2008, Kenakalan Remaja (Juvenile Deliquency), Yogyakarta: Fakultas Psikologi Universitas Gadjah Mada Yogyakarta.

\section{Peraturan Perundang-undangan:}

Undang-Undang Republik Indonesia No. 3 Tahun 1997 tentang Pengadilan Anak.

Undang-Undang Republik Indonesia No. 39 Tahun 1999 tentang Hak Asasi Manusia.

Undang-Undang Republik Indonesia No. 23 Tahun 2002 tentang Perlindungan Anak.
Undang-Undang Republik Indonesia No. 11 Tahun 2012 tentang Peradilan Pidana Anak.

Keputusan Presiden Republik Indonesia No. 36 Tahun 1990 tentang Pengesahan Convention on the Right of the Child (Konvensi Hak Anak).

United Nation, United Nation Standard Minimum Rules for the Administration of Juvenile Justice ("The Beijing Rules"), Adopted by General Assembly resolution 40/33 of 29 November 1985.

United Nation, Convention on The Right of The Child, 1989. 